\title{
Green supply chain practices and its impact on community empowerment and poverty reduction in Indonesia
}

\author{
Tri Siwi Nugrahani ${ }^{a^{*}}$, Suharni ${ }^{b}$, Rosalia Indriyati Saptatiningsih ${ }^{\mathfrak{c}}$ and Mohamed Nor Azhari \\ Azmand
}

${ }^{a}$ Department of Accounting, Faculty of Economics, University of PGRI Yogyakarta, Campus Universitas PGRI Yogyakarta, Jl. PGRI I, No.117 Yogyakarta, Indonesia

${ }^{b}$ University of PGRI Yogyakarta, Faculty of Teacher and Education, Department of Counseling, Campus Universitas PGRI Yogyakarta, Jl. PGRI I, No. 117 Yogyakarta, Indonesia

${ }^{c}$ University of PGRI Yogyakarta, Faculty of Teacher and Education, Departement of Civic and Education, Campus Universitas PGRI Yogyakarta, Jl. PGRI I, No.117 Yogyakarta, Indonesia

${ }^{d}$ Faculty of Technical and Vocational, Universiti Pendidikan Sultan Idris, 35900 Tanjong Malim, Perak, Malaysia

\section{H R O N I C L E}

Article history:

Received July 29, 2019

Received in revised format

August 28, 2019

Accepted September 262019

Available online

September 262019

Keywords:

Community empowerment

Social welfare

Poverty

Green supply chain

\section{Introduction}

Community participation is a superior social capital to achieve optimal construction. Social capital includes beliefs, norms, and social networks which can facilitate collective action (Adler \& Kwon, 2000, 2002; Coleman, 1988). Social capital is emphasized on community togetherness to improve the quality of life together and make better changes and continuous adjustments (Chiu et al., 2006; Daniel et al., 2003). It is the ability of the community to associate with each other to build an important force, not only economically but also socially (Kusumastuti, 2015). Every community has the resources that can be accessed and utilized by its members. Community is the potential of social capital so that the community contributes to meeting the needs and common interests. During the last decade, green supply chain practices have covered both traditional and contemporary trends in both business world and economies (Linton et al., 2007; Rao \& Holt, 2005; Srivastava, 2007). It is defined as the core field

* Corresponding author

E-mail address: trisiwi@upy.ac.id (T. S. Nugrahani)

C) 2020 by the authors; licensee Growing Science. doi: 10.5267/j.uscm.2019.9.002 
of management which integrates various environmental issues and risk factors in the shadow of ecological efficiency, starting from the production of the product and finally delivering it to ending consumers (Hsu et al., 2016; Kibert, 2016; Vermeulen, 2015). In this regard, green supply chain is adopting the idea of internal health and environmental sustainability by means of the capability of selfcorrection information from external market. In this regard, various external factors like rules and regulation, government policies and their implications, social norms and values are important as well. It is a common notion that green supply chain management practices is an organizational related action that are influenced by various external forces. In this way, the role of institutional theory is very important which widely provides the theoretical discussion for the significance of green supply chain management. This research examines the influence of green supply chain management practices on the community empowerment and poverty reduction factors in the region of Indonesia. This study addresses three main factors of supply chain: eco-design, environmentally friendly approach, and green manufacturing and distribution to analyze their influence on community empowerment and poverty reduction. This research contributes to the literature and perceptions of poverty reduction efforts in education, environment, health, and economics.

\section{Literature Review}

Poverty reduction efforts entrusted to the community itself are supported and facilitated by the government, private sector and other civil society organizations, so that the poverty reduction process would become a community movement which would ensure independence and sustainability of the potential to improve a more decent life (Ningsih et al., 2015; Omran \& Kamran, 2018). The development of economic theory addresses high-income countries to middle-income countries through innovation by developing economic systems that guide the process of industrialization, urbanization, and modernization by contributing Chinese wisdom to the improvement and development of the economic theory (Kamran et al., 2019; Turok \& McGranahan, 2013). Currently, economists are beginning to use a subjective approach to happiness and satisfaction to measure the quality of life as an effort to reduce poverty (Sariffuddin \& Susanti, 2011). Quality of life consists of guaranteeing fulfillment of basic needs and services, alleviating poverty, and protecting children, women and marginal homes. The capacity of Indonesian human life includes mental revolution, community empowerment, and capacity building for innovation and technology. Macro quality measurement or poverty reduction stipulates that the human development index includes health, education and a decent life. How to measure development is by measuring the median of wealth, equity, quality of life, environmental degradation, sustainable social justice. Cronin et al. (2017) researched in Indonesia by revealing that all households need to pay attention to the level of health with an $8.5 \%$ result of access to irrigation and sanitation and must comply with the 2017 MDG target. According to Schneider (2018) in Brazil there is a need to care about health. The level of health is tested by Leptospira, a disease that causes global morbidity and mortality, especially in slums.

The Indonesian government should examine the level of poverty for people with disabilities. About 74 percent of the poor people in Indonesia have received rice from the poor (Raskin) recently, and 73 percent of poor non-disabled households received Raskin. This shows that the Indonesian government still applies the same treatment to overcome the problem of poverty with disabilities. Meanwhile, Persons with Disabilities (PWD) has several weaknesses that are not experienced by people who do not have physical disability (Bella \& Dartanto, 2018). Rustiadi and Nasution (2017) examined poverty related to access to social capital and other factors that determine the welfare of rural households. The results of his research prove that social capital has an important role in reducing poor households. Investment in household social capital can potentially reduce rural poverty. The poverty reduction program in rural Indonesia is focused on development through infrastructure investment and human resources including education, health, and access to financial capital. Planned and measured actions on investment in rural social capital need to be considered because they have proven to have a positive impact on access to social capital through household participation in social groups. This study shows that government and private sector intervention in the provision of quality education encourages 
increased social capital, which, in turn, also may also increase incomes and reduce poverty in rural areas. Poverty can refer to the condition of the individual, group, or collective situation of the community. Mass and severe poverty are generally found in developing countries. However, there is an evidence of poverty also occurring in developed countries. Poverty in developing countries is related to structural aspects, such as an unfair economic system, Corruption Collusion Nepotism (KKN), rampant social discrimination, or no social security. While poverty in developed countries is more individual, for example experiencing disability (mental or physical), age, severe and prolonged addiction, or alcoholism. This condition usually gives birth to homeless people who roam or single families, generally experienced by mothers whose lives depend on social assistance from the government, such as food stamps or family allowances (Suharto, 2009). Therefore, in addition to understanding the problem of poverty, it is also necessary to understand the problem of community empowerment originating from the community or community about the hopes of economic development in an effort to reduce poverty and a sustainable environment.

The Malaysia Household Income Survey (HIS) illustrates the vulnerability of Malaysian households under the income pyramid in the income range of USD10-USD50 a day (Rodrigo, 2017). Those at the bottom of the pyramid are considered poor workers. The group can further be distinguished between 'almost poor' and 'new poor' groups. Kumara and Gunewardena (2017) studies, analyzed the poverty rates of households in Sri Lanka which were divided into health, education, and standard living elements between a number of poor households. The study also examined the success of village development regarding the success of all poor families divided by disabled members and not families.

The results of the study showed that households with people with disabilities faced higher poverty problems compared with RT without disability members. Therefore, poverty reduction in Sri Lanka, especially poverty alleviation among disabled households needs to be improved in terms of health, education and living standards. Bella and Dartanto (2018) stated that the heads of disabled households in Indonesia tend to be poorer with a poverty gap index rate of 2.6 percent. Blind heads of households are less likely to be poor compared with other people with disabilities. In addition, household heads who have congenital defects (birth defects) have a poorer probability of 4.8 percent and have a poverty gap index of around 7.8 percent. Resources for poverty alleviation are far better used as a result of careful local-based investigations. Factors related to poverty reduction in India can be specifically controlled through appropriate public intervention. Health and debt have strong links with poverty and interact with reducing household poverty. Affordable health services can access cheaper consumer credit and can help reduce household poverty (Barlogie et al., 2006). Numerous studies have provided their theoretical contribution while focusing the factor of green supply chain management and its relationship with the community empowerment and other social welfare factors (Koh et al., 2013; Luthra et al., 2015; Wang et al., 2013). For example, Choi and Hwang (2015) examined the factor of e-business and its application for the operational performance of buyer-seller relationship which ultimately impact on the overall society. Their findings show that the development of information and communication technology can significantly influence on the business and on the overall society too. In this regard, the role of e-business cannot be ignored. Chin et al. (2015) empirically investigated the role of green supply chain in environmental and sustainable development. They explained that increasing attention of green supply chain integrated various fields of research like total environment, involvement of the organization in such practices, and working for the sustainable performance enhancement.

\section{Research Methods and Data collection}

This study has been carried out in the region of Indonesia. For the data collection, three main factors of Green supply chain under the title of eco-design, environmentally friendly approach, and green manufacturing and distribution have been considered and measured on five points Likert scale, for ecodesign and environmentally friendly six items, and for green manufacturing and distribution five items are added in the questionnaire. For community empowerment, five items have been also observed as 
core indicators of the first endogenous variable of the study. In addition, for the measurement of poverty reduction, factors like Income related strategy, development related strategy, employment related strategy, social welfare were added in the questionnaire. After the development of the questionnaire a sample of 305 respondents was collected. For the purpose of analysis, descriptive statistics, confirmatory factor analysis, structural equation modelling, and regression analysis were applied.

\section{Results and Discussions}

Table 1 shows the descriptive findings of the study covering various dimensions of supply chain and community empowerment in the region of Indonesia. For the measurement of supply chain, green supply chain items have been considered. For this purpose, mean score, deviation from the mean and variance in the mean score has been also calculated and presented. In addition, mean score and other descriptive measures for the community development are also presented.

Table 1

Descriptive Statistics

\begin{tabular}{|c|c|c|c|c|c|c|c|c|}
\hline Variable & $\mathbf{N}$ & Range & Minimum & Maximum & & Mean & Std. Deviation & Variance \\
\hline Items & Statistic & Statistic & Statistic & Statistic & Statistic & Std. Error & Statistic & Statistic \\
\hline GSC1 & 305 & 4.00 & 1.00 & 5.00 & 3.7934 & .07074 & 1.23542 & 1.526 \\
\hline GSC2 & 305 & 4.00 & 1.00 & 5.00 & 2.8393 & .07654 & 1.33664 & 1.787 \\
\hline GSC3 & 305 & 4.00 & 1.00 & 5.00 & 3.1410 & .07005 & 1.22332 & 1.497 \\
\hline GSC4 & 305 & 4.00 & 1.00 & 5.00 & 3.1738 & .06934 & 1.21096 & 1.466 \\
\hline GSC5 & 305 & 4.00 & 1.00 & 5.00 & 3.3115 & .07354 & 1.28428 & 1.649 \\
\hline GSC6 & 305 & 4.00 & 1.00 & 5.00 & 3.4131 & .07089 & 1.23803 & 1.533 \\
\hline GSCM1 & 305 & 4.00 & 1.00 & 5.00 & 3.1607 & .06866 & 1.19913 & 1.438 \\
\hline GSCM2 & 305 & 4.00 & 1.00 & 5.00 & 3.0000 & .07089 & 1.23810 & 1.533 \\
\hline GSCM3 & 305 & 4.00 & 1.00 & 5.00 & 2.9279 & .07346 & 1.28300 & 1.646 \\
\hline GSCM4 & 305 & 4.00 & 1.00 & 5.00 & 3.0951 & .08086 & 1.41217 & 1.994 \\
\hline GSCM5 & 305 & 4.00 & 1.00 & 5.00 & 3.6623 & .07227 & 1.26207 & 1.593 \\
\hline GSCM6 & 305 & 4.00 & 1.00 & 5.00 & 3.1705 & .07189 & 1.25543 & 1.576 \\
\hline GSCMA & 305 & 4.00 & 1.00 & 5.00 & 2.9705 & .07777 & 1.35813 & 1.845 \\
\hline GSCMB & 305 & 4.00 & 1.00 & 5.00 & 3.3902 & .06862 & 1.19837 & 1.436 \\
\hline GSCMC & 305 & 4.00 & 1.00 & 5.00 & 3.0721 & .07663 & 1.33822 & 1.791 \\
\hline GSCMD & 305 & 4.00 & 1.00 & 5.00 & 3.3967 & .07307 & 1.27604 & 1.628 \\
\hline GSCME & 305 & 4.00 & 1.00 & 5.00 & 3.4492 & .06597 & 1.15203 & 1.327 \\
\hline CE1 & 305 & 4.00 & 1.00 & 5.00 & 2.6426 & .07923 & 1.38370 & 1.915 \\
\hline CE2 & 305 & 4.00 & 1.00 & 5.00 & 2.9607 & .07055 & 1.23215 & 1.518 \\
\hline CE3 & 305 & 4.00 & 1.00 & 5.00 & 3.0852 & .07238 & 1.26411 & 1.598 \\
\hline CE4 & 305 & 4.00 & 1.00 & 5.00 & 3.3049 & .07185 & 1.25478 & 1.574 \\
\hline CE5 & 305 & 4.00 & 1.00 & 5.00 & 3.0393 & .07754 & 1.35424 & 1.834 \\
\hline CE6 & 305 & 4.00 & 1.00 & 5.00 & 3.3016 & .07091 & 1.23843 & 1.534 \\
\hline
\end{tabular}

After the development of the descriptive findings, Fig. 1 below provides a structural view for the various items of supply chain factors (F1, F2, and F3).

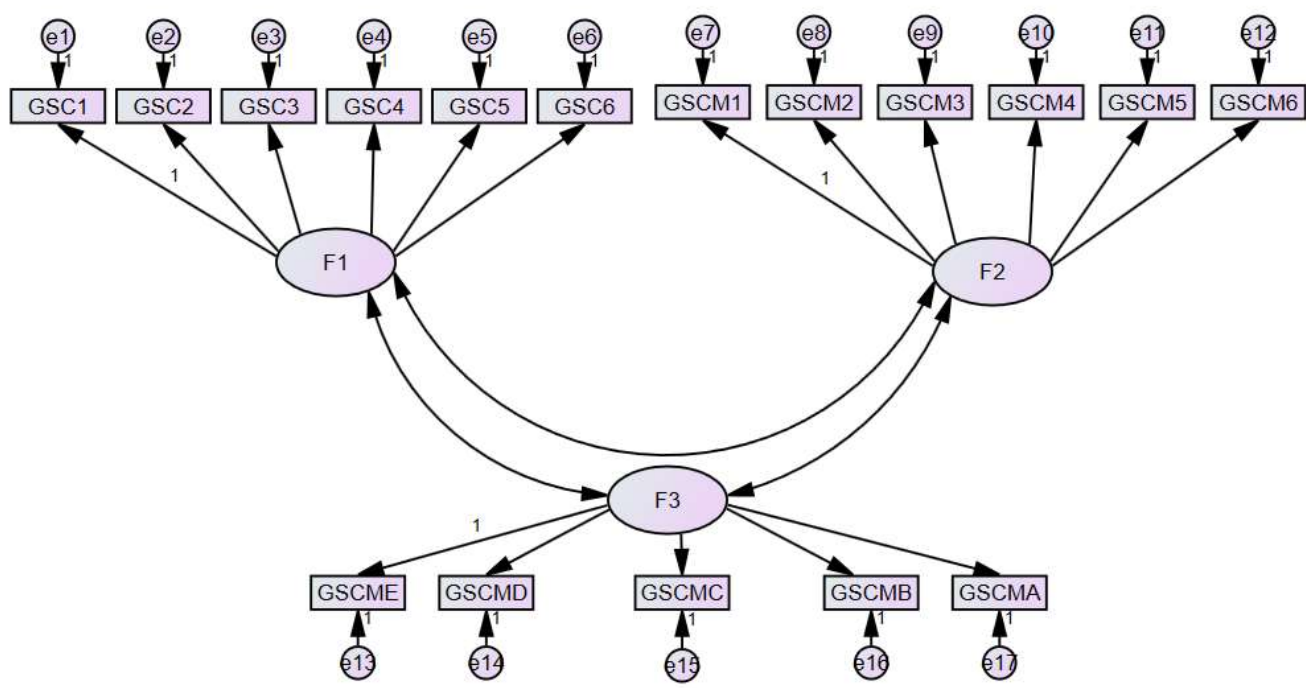

Fig. 1. Structural Model for Confirmatory Factor Analysis (CFA): Green Supply Chain Management 
It is found that for the F1, six items, for F2, six items and for F3, five items are added in the model. For the measurement of covariance and correlation between these factors, double headed arrows are developed and presented in the same figure. Whereas individual items for each of the latent variable are presented through single headed arrow, along with the error terms of the model. After the development of this model, confirmatory factor analysis CFA was performed, and findings are presented Under Table 2 and Table 3 respectively. After the calculation of factor loadings through CFA, Table 2 provides the model fit indices. It is observed that the value of the Chi-Square is significant at 1 percent, GFI is 89.1 percent, AGFI is 88.2 percent, TLI is 87.2 percent, CFI is 89.6 percent and PCFI is 85.6 percent, respectively. All these values are providing the fact that CFA is quite accepted and there is no problem for the fitness of the model. In addition, the value of RMSEA is below 0.05, providing further evidence for the fitness of the CFA.

Table 2

Model Fit indices of for CFA

\begin{tabular}{lll}
\hline Description of Fit Measurement & Value achieved & Accepted/Not accepted \\
\hline Chi-square & 472.394 & Accepted \\
Probability value & 0.000 & Accepted \\
GFI & 0.891 & Accepted \\
AGFI & 0.882 & Accepted \\
TLI & 0.872 & Accepted \\
CFI & 0.896 & Accepted \\
PCFI & 0.858 & Accepted \\
RMSEA & 0.049 & Accepted \\
\hline
\end{tabular}

Table 3 provides the factors loadings through CFA for each of the latent indicator of green supply chain factors. It is found that for GSC1 to GSC6, factor loadings are in range of .721 to .880, respectively. While the factor loadings for the latent indicators of GSCM are also in reasonable range, providing the fact that there is no problem for their factor loadings. However, minimum factor loadings are .661 and .69 as presented by GSCM3 and GSCM2, respectively. In addition, for F3, the highest factor loading is represented by GSCME which is .883, and the lowest is given by GSCMA which is .712. All these values are defending the argument that there is no problem for the factor loadings, and they are finally accepted for their consideration in the structural equation model (SEM) analysis which presents the effect of green supply chain management on community empowerment in the region of Indonesia. For better understanding of the CFA, Fig. 2 provides the items of the latent variables along with their relative factor loadings through standardized values.

Table 3

Standardized Regression Weights: (Group number 1 - Default model)

\begin{tabular}{cccc}
\hline Items & Direction & Latent Variables & Estimate \\
\hline GSC1 & $\leftarrow-$ & F1 & .810 \\
GSC2 & $\leftarrow-$ & F1 & .831 \\
GSC3 & $\leftarrow-$ & F1 & .721 \\
GSC4 & $\leftarrow-$ & F1 & .880 \\
GSC5 & $\leftarrow-$ & F1 & .853 \\
GSC6 & $\leftarrow-$ & F1 & .761 \\
GSCM1 & $\leftarrow-$ & F2 & .770 \\
GSCM2 & $\leftarrow-$ & F2 & .691 \\
GSCM3 & $\leftarrow-$ & F2 & .661 \\
GSCM4 & $\leftarrow-$ & F2 & .823 \\
GSCM5 & $\leftarrow-$ & F2 & .864 \\
GSCM6 & $\leftarrow-$ & F2 & .720 \\
GSCME & $\leftarrow-$ & F3 & .883 \\
GSCMD & $\leftarrow-$ & F3 & .761 \\
GSCMA & $\leftarrow-$ & F3 & .712 \\
GSCMC & $\leftarrow-$ & F3 & .820 \\
GSCMB & $\leftarrow-$ & F3 & .861 \\
\hline
\end{tabular}




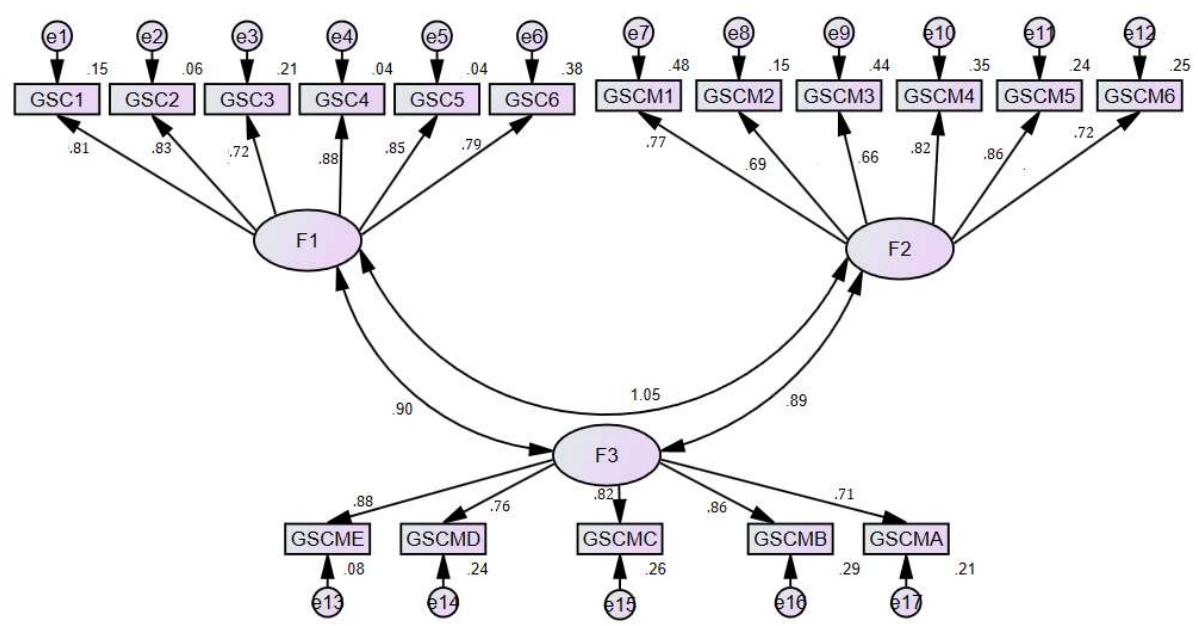

Fig. 2. Output for Confirmatory Factor Analysis (CFA): Green Supply Chain Management

After the CFA output for the latent variables of green supply chain management, Fig. 3 provides the structural view for various items of community empowerment CE. These items are ranging from CE1 to CE6 with their relevant error terms too.

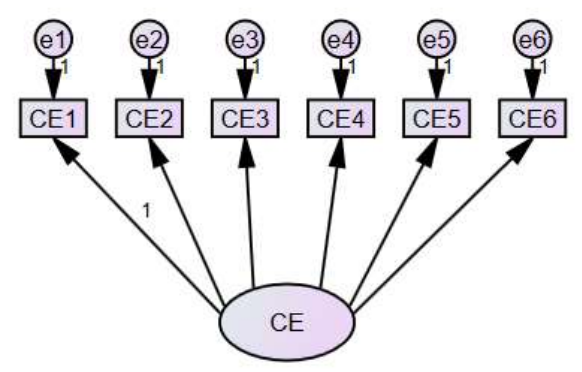

Fig. 3. Structural Model for Confirmatory Factor Analysis (CFA): Community Empowerment (CE). The output for the CFA with its model fit and factor loadings are presented under Table 4 and Fig. 4, respectively.

\section{Table 4}

Model Fit indices of for CFA

\begin{tabular}{lll}
\hline Description of Fit Measurement & Value achieved & Accepted/Not accepted \\
\hline Chi-square & 21.15 & Accepted \\
Probability value & 0.005 & Accepted \\
GFI & .956 & Accepted \\
AGFI & .943 & Accepted \\
TLI & .961 & Accepted \\
CFI & .982 & Accepted \\
PCFI & .868 & Accepted \\
RMSEA & .023 & Accepted \\
\hline
\end{tabular}

For Model fit indices, all measures like GFI, AGFI, TLI, AGFI, CFI, PCFI and RMSEA provide the fact that there is no problem for the CFA for CE. In addition, All factor loeading values are acceptable as literature findings reasonable defend the argument that factor loading above .60 can be considered. In addition, after the CFA, Fig. 5 provides the graphical view of structural model of the study, covering the latent variables for green supply chain management named as; F1, F2, and F3 respectively. Whereas, for community empowerment, latent variable or endogenous variable is named as CE along with six items as presented earlier under CFA. 


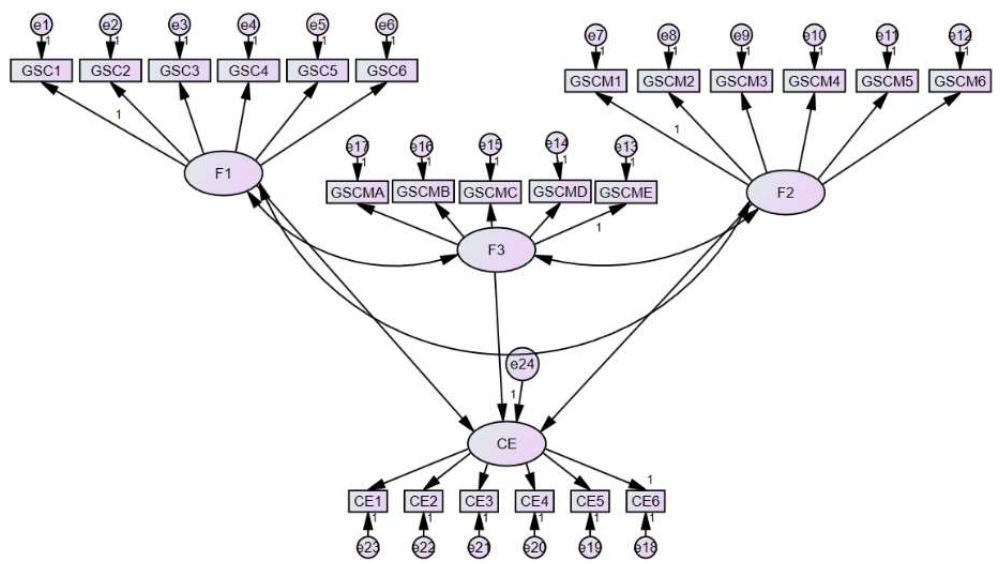

Fig. 4. Output for Confirmatory Factor Analysis (CFA): Community Empowerment (CE)

For the structural relationship between exogenous and endogenous variables, single headed arrow, approaching from F1 to CE, F2 to CE and F3 to CE are also presented under Fig. 5. In addition, each indicator of latent variable has also presented a unique error term ranging from e1 to e23, while e24 indicates the unique error term over endogenous variable of the study. Table 5 provides the outcome for the structural model of the study, covering the standardized regression estimates, standard error, critical ratios and their related p-values. It is observed that the effect of F1 on CE is .475 with the standard error of .085 respectively. It shows that F3 of green supply chain management is positively and significantly impacting on community empowerment in Indonesia. This effect is significant at 1 percent as p-value is highly significant. It shows that the factor of green supply chain management in the form of Eco-design (F1), has positive and significant impact on the community development in Indonesia. For F2 (environmentally friendly approach), impact on CE is . 310 with the standard error of 0.037. It shows that the more the green supply chain management activities in the form of environment friendly, the more the constructive influence on CE in the region of Indonesia. This fact has further supported the fact that green supply is beneficial for the local community only when it is performed in an environment friendly way. Besides, the third factor of green supply chain in the form of green manufacturing and distribution (F3), coefficient of 2.110 indicates a highly positive and significant influence with the standard error of .916. It explains that community empowerment is possible in the region of Indonesia with the green manufacturing and green distribution practices. Overall, all three exogenous variables of green supply chain practices have shown their positive impacts on CE.

Table 5

Regression Findings for SEM of Impact of Green Supply Chain on Community Empowerment (CE)

\begin{tabular}{ccccccc}
\hline Endogenous Variable & Direction & Exogenous Variable & Estimate & S.E. & C.R. & P \\
\hline $\mathrm{CE}$ & $\leftarrow$ & $\mathrm{F} 2$ & .310 & .037 & 8.37 & $* * *$ \\
$\mathrm{CE}$ & $\leftarrow$ & $\mathrm{F} 3$ & 2.110 & .916 & 2.30 & $* *$ \\
$\mathrm{CE}$ & $\leftarrow$ & $\mathrm{F} 1$ & .475 & .085 & 5.58 & $* * *$ \\
\hline
\end{tabular}

\subsection{Impact of Green SCCM on poverty reduction}

After the development of structural model for the impact of green supply chain practices on community empowerment, next step is to examine its impact on poverty reduction in the region of Indonesia. Table 6-9 provide the empirical findings, for the impact of green supply chain factors (F1-F3) through mean value on poverty reduction factors. Under Table 6, poverty reduction is measured and considered through income related strategy over a Likert scale of five points $(1=$ strongly disagree, $5=$ strongly agree). It is found that the effect of mean score of F1 or Mean Eco-design activities for the green supply chain on poverty reduction through income related strategy is 0.188 . It shows that there is a significant and positive influence of $\mathrm{F} 1$ on first measure of poverty reduction, significant at 1 percent $(\mathrm{t}=2.89$, $\mathrm{p}=0.004$ ). However, through F2 (mean environmentally friendly approaches), effect on poverty 
reduction through income related strategy is negative and insignificant. Whereas F3 has shown its significant and positive impact with the coefficient of .22 and standard error of 0.59 . It means that the more the green manufacturing and distribution related activities in Indonesia, the more positive effect on poverty reduction with income related strategies.

Table 6

Regression Findings for Impact of Green Supply Chain on Poverty Reduction

\begin{tabular}{|c|c|c|c|c|c|}
\hline Poverty Reduction (Income Related Strategy) & Coef. & St.Err & t-value & p-value & Sig. \\
\hline F1 Mean Eco Design & 0.188 & 0.065 & 2.89 & 0.004 & $* * *$ \\
\hline F2 Mean Environmentally Friendly Approaches & -0.062 & 0.069 & -0.90 & 0.371 & \\
\hline F3 Mean Green manufacturing and Distribution & 0.222 & 0.059 & 3.76 & 0.000 & $* * *$ \\
\hline cons & 1.468 & 0.315 & 4.66 & 0.000 & $* * *$ \\
\hline Mean dependent var & \multicolumn{2}{|c|}{2.643} & dent var & \multicolumn{2}{|r|}{1.384} \\
\hline R-squared & \multicolumn{2}{|c|}{0.168} & f obs & \multicolumn{2}{|r|}{305.000} \\
\hline F-test & \multicolumn{2}{|c|}{7.372} & & \multicolumn{2}{|r|}{0.000} \\
\hline Akaike crit. (AIC) & 1049.031 & \multicolumn{2}{|c|}{ Bayesian crit. (BIC) } & \multicolumn{2}{|c|}{1063.912} \\
\hline
\end{tabular}

Table 7 predicts the effect of all three factors of green supply chain on development related strategy of poverty reduction in Indonesia. It is observed that all three factors of green supply chain have shown their highly positive and significant influence while lowering the problem of poverty. However, the coefficient of F2 has shown the highest positive influence of 0.262 , followed by F3 (coefficient $=.257$ ), and finally F1 (coefficient $=.172$ ). In terms of explained variation, overall value of $\mathrm{R}^{2}$ is 24.0 , while Ftest is highly significant at 5 percent, indicating that all the regression coefficients are significantly different from zero.

Table 7

Regression Findings for Impact of Green Supply Chain on Poverty Reduction

\begin{tabular}{lccccc}
\hline Poverty Reduction Development Related Strategy & Coef. & St.Err & t-value & p-value & Sig. \\
\hline F1 Mean Eco Design & 0.172 & 0.052 & 3.30 & 0.001 & $* * *$ \\
F2 Mean Environmentally Friendly Approaches & 0.262 & 0.056 & 4.69 & 0.000 & $* * *$ \\
F3 Mean Green manufacturing and Distribution & 0.257 & 0.047 & 5.42 & 0.000 & $* * *$ \\
$\quad$ cons & 0.716 & 0.253 & 2.83 & 0.005 & $* * *$ \\
\hline Mean dependent var & \multicolumn{2}{c}{2.961} & SD dependent var & 1.232 \\
R-squared & \multicolumn{2}{c}{0.240} & Number of obs & 305 \\
F-test & 31.638 & Prob $>$ F & 0.000 \\
Akaike crit. (AIC) & 916.295 & Bayesian crit. (BIC) & 931.177 \\
\hline
\end{tabular}

Note: $* * * \mathrm{p}<0.01, * * \mathrm{p}<0.05, * \mathrm{p}<0.1$

Table 8

Regression Findings for Impact of Green Supply Chain on Poverty Reduction

\begin{tabular}{|c|c|c|c|c|c|}
\hline Poverty Reduction: Employment Related Strategy & Coef. & St.Err & t-value & p-value & Sig. \\
\hline F1 Mean Eco Design & 0.192 & 0.055 & 3.50 & 0.001 & $* * *$ \\
\hline F2 Mean Environmentally Friendly Approaches & 0.203 & 0.059 & 3.47 & 0.001 & $* * *$ \\
\hline F3 Mean Green manufacturing and Distribution & 0.266 & 0.050 & 5.34 & 0.000 & *** \\
\hline cons & 0.927 & 0.266 & 3.49 & 0.001 & **** \\
\hline Mean dependent var & 3.085 & \multicolumn{2}{|c|}{ SD dependent var } & \multicolumn{2}{|r|}{$\begin{array}{r}1.264 \\
305000\end{array}$} \\
\hline R-squared & 0.205 & \multicolumn{2}{|c|}{ Number of obs } & \multirow{2}{*}{\multicolumn{2}{|c|}{$\begin{array}{r}305.000 \\
0.000\end{array}$}} \\
\hline F-test & 25.857 & \multicolumn{2}{|c|}{ Prob $>$ F } & & \\
\hline Akaike crit. (AIC) & 945.581 & \multicolumn{2}{|c|}{ Bayesian crit. (BIC) } & \multicolumn{2}{|r|}{0.000} \\
\hline
\end{tabular}

Table 8 presents regression findings for the effect of green supply chain practices on poverty reduction measurement through employment related strategy. It is found that all three measures have shown a highly significant and positive influence on poverty reduction indicator. As per the model fitness, Ftest is significant at 5 percent, and overall explained variation of 20.5 percent in the outcome factor of the study. Similarly, Table 9 shows the fact that green supply chain practices have shown a highly significant and positive influence on poverty reduction through social welfare. 
Table 9

Regression Findings for Impact of Green Supply Chain on Poverty Reduction

\begin{tabular}{lrrrrr}
\hline \multicolumn{1}{c}{ Poverty Reduction: Social Welfare } & Coef. & St.Err & t-value & p-value & Sig. \\
\hline F1 Mean Eco Design & 0.205 & 0.053 & 3.83 & 0.000 & $* * *$ \\
F2 Mean Environmentally Friendly Approaches & 0.251 & 0.057 & 4.40 & 0.000 & $* * *$ \\
F3 Mean Green manufacturing and Distribution & 0.247 & 0.049 & 5.08 & 0.000 & $* * *$ \\
$\quad$ cons & 1.001 & 0.259 & 3.86 & 0.000 & $* * *$ \\
\hline Mean dependent var & \multicolumn{3}{c}{3.305} & SD dependent var & 1.255 \\
R-squared & & 0.233 & Number of obs & 305.000 \\
F-test & & 30.425 & Prob $>$ F & 0.000 \\
Akaike crit. (AIC) & & 930.219 & Bayesian crit. (BIC) & 945.100 \\
Note: ${ }^{* *} \mathrm{p}<0.01, * * \mathrm{p}<0.05,{ }^{*} \mathrm{p}<0.1$ & & & & &
\end{tabular}

\section{Conclusion and Recommendations}

This study has focused on the factor of green supply chain management practices and their impacts on the community empowerment and poverty reduction in the region of Indonesia. Primary data was collected and analyzed for examining the relationship between exogenous and endogenous variables of the study. Structural equation modelling approach was applied for checking the impacting of green supply chain management practices on community empowerment. It was found that all three factors of green supply chain have shown their positive and highly significant influences on CE. In addition, findings under regression analysis justifies the positive influence on supply chain practices in reducing the poverty issue in Indonesia. The findings under present study has justified the constructive role of green practices of supply chain in dynamic nature of the society. Business organizations that implement such practices can increase their performance and also contribute in the society while filling their social obligations. In addition, the study contribution can be viewed while filling the gap in the literature for integrating supply chain practices with community progress and overall welfare through poverty reduction. However, there are some limitations to this study. First, this research is conducted in the region of Indonesia with limited regional implications. Second, the study has primarily focused on primary measures of green supply chain and their impact on community empowerment and poverty reduction. Future studies should overcome these limitations with the expansion of regional implications and taking the secondary measures for green supply chain, community empowerment, and poverty reduction.

\section{References}

Adler, P. S., \& Kwon, S.-W. (2000). Social capital: The good, the bad, and the ugly. Knowledge and social capital, 89.

Adler, P. S., \& Kwon, S.-W. (2002). Social capital: Prospects for a new concept. Academy of management review, 27(1), 17-40.

Barlogie, B., Tricot, G., Anaissie, E., Shaughnessy, J., Rasmussen, E., Van Rhee, F., . . Pineda-Roman, M. (2006). Thalidomide and hematopoietic-cell transplantation for multiple myeloma. New England Journal of Medicine, 354(10), 1021-1030.

Bella, A., \& Dartanto, T. (2018). Persons with disabilities (PWD) and poverty in Indonesia. Malaysian Journal of Economic Studies, 55(2), 167-188.

Chin, T. A., Tat, H. H., \& Sulaiman, Z. (2015). Green supply chain management, environmental collaboration and sustainability performance. Procedia Cirp, 26, 695-699.

Chiu, C.-M., Hsu, M.-H., \& Wang, E. T. (2006). Understanding knowledge sharing in virtual communities: An integration of social capital and social cognitive theories. Decision support systems, 42(3), 18721888 .

Choi, D., \& Hwang, T. (2015). The impact of green supply chain management practices on firm performance: the role of collaborative capability. Operations Management Research, 8(3-4), 69-83.

Coleman, J. S. (1988). Social capital in the creation of human capital. American journal of sociology, 94, S95-S120.

Cronin, A. A., Odagiri, M., Arsyad, B., Nuryetty, M. T., Amannullah, G., Santoso, H., \& Darundiyah, K. (2017). Piloting water quality testing coupled with a national socioeconomic survey in Yogyakarta 
province, Indonesia, towards tracking of Sustainable Development Goal 6. International journal of hygiene and environmental health, 220(7), 1141-1151.

Daniel, B., Schwier, R., \& McCalla, G. (2003). Social capital in virtual learning communities and distributed communities of practice. Canadian Journal of Learning and Technology/La revue canadienne de l'apprentissage et de la technologie, 29(3).

Hsu, C.-C., Tan, K.-C., \& Mohamad Zailani, S. H. (2016). Strategic orientations, sustainable supply chain initiatives, and reverse logistics: Empirical evidence from an emerging market. International journal of operations \& production management, 36(1), 86-110.

Kamran, H. W., Arshad, S. B., \& Omran, A. (2019). Country Governance, Market Concentration and Financial Market Dynamics for Banks Stability in Pakistan.

Kibert, C. J. (2016). Sustainable construction: green building design and delivery: John Wiley \& Sons.

Koh, S. L., Genovese, A., Acquaye, A. A., Barratt, P., Rana, N., Kuylenstierna, J., \& Gibbs, D. (2013). Decarbonising product supply chains: design and development of an integrated evidence-based decision support system-the supply chain environmental analysis tool (SCEnAT). International Journal of Production Research, 51(7), 2092-2109.

Kumara, P., \& Gunewardena, D. (2017). Disability and poverty in Sri Lanka: A household level analysis. Sri Lanka Journal of Social Sciences, 40(1).

Kusumastuti, A. (2015). Modal sosial dan mekanisme adaptasi masyarakat pedesaan dalam pengelolaan dan pembangunan infrastruktur. Masyarakat: Jurnal Sosiologi, 81-97.

Linton, J. D., Klassen, R., \& Jayaraman, V. (2007). Sustainable supply chains: An introduction. Journal of operations management, 25(6), 1075-1082.

Luthra, S., Garg, D., \& Haleem, A. (2015). An analysis of interactions among critical success factors to implement green supply chain management towards sustainability: An Indian perspective. Resources Policy, 46, 37-50.

Ningsih, U. W., Sukesi, K., Nugroho, H. U., \& Shinta, A. (2015). Preserving the Environment and Alleviating Poverty Through Household Waste Management. International Journal of Social and Local Economic Governance, 1(2), 104-107.

Omran, A., \& Kamran, H. W. (2018). Determining the Factors Attracting the Tourists to Visit Kedah State, Malaysia. Journal of Environmental Management \& Tourism, 9(2 (26)), 355-364.

Rao, P., \& Holt, D. (2005). Do green supply chains lead to competitiveness and economic performance? International journal of operations \& production management, 25(9), 898-916.

Rodrigo, S. K. (2017). Working for Welfare: Inequality and Shared Vulnerability among the Malaysian Middle Classes. Malaysian Journal of Economic Studies, 53(1), 9-31.

Rustiadi, E., \& Nasution, A. (2017). Can Social Capital Investment Reduce Poverty in Rural Indonesia? International Journal of Economics and Financial Issues, 7(2), 109-117.

Sariffuddin, S., \& Susanti, R. (2011). Penilaian kesejahteraan masyarakat untuk mendukung permukiman berkelanjutan di Kelurahan Terboyo Wetan, Semarang. Makara, Sosial Humaniora, 15(1), 29-42.

Schneider, R. M. (2018). Brazil: culture and politics in a new industrial powerhouse: Routledge.

Srivastava, S. K. (2007). Green supply-chain management: a state-of-the-art literature review. International journal of management reviews, 9(1), 53-80.

Turok, I., \& McGranahan, G. (2013). Urbanization and economic growth: the arguments and evidence for Africa and Asia. Environment and Urbanization, 25(2), 465-482.

Vermeulen, W. J. (2015). Self-governance for sustainable global supply chains: can it deliver the impacts needed? Business Strategy and the Environment, 24(2), 73-85.

Wang, Y.-F., Chen, S.-P., Lee, Y.-C., \& Tsai, C.-T. S. (2013). Developing green management standards for restaurants: An application of green supply chain management. International Journal of Hospitality Management, 34, 263-273.

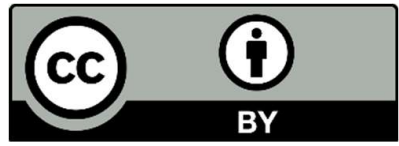

(C) 2020 by the authors; licensee Growing Science, Canada. This is an open access article distributed under the terms and conditions of the Creative Commons Attribution (CC-BY) license (http://creativecommons.org/licenses/by/4.0/). 